of $9000 l$, an income which is derived from a variety of sources:-Treasury grant, 400ol.; Gassiot Fund, 40ol. (about); from Meteorological Committee, 40ol.; fees, \&c., $4200 l$. (about). In addition to this there has been I20ol. in donations.

Whether the laboratory can become self-supporting is a matter of doubt to my mind. Even if it should be so, that is no reason for taking it away from State control, which always gives an impress to decisions, and it is a pledge that gain is not its only object. Certainly it would never arrive at the proportions that the huge, more than self-supporting department, the Post Office, has arrived at. The example of Germany, where the State takes the fees, and supports the institution, is worth following.

\section{THE BEN BULBEN DISTRICT.}

THE region lying north of Sligo, which was visited by a large party of naturalists last July on the occasion of the fourth triennial conference of the Naturalists' Field Clubs of Ireland, is one of much beauty and interest. In its general aspect it recalls the best features of the Yorkshire Carboniferous Limestone area. Its setting, with the great limestone plain of Ireland stretching away on one hand, and the Atlantic Ocean on another, adds a dignity and impressiveness to this group of cliff-rimmed, fiat-topped hills which might not be bestowed by their height alone, though they are of no mean elevation (Truskmore, the highest point, rises to $2 \mathrm{II}_{3}$ feet). The Ben Bulben range,

\begin{tabular}{|c|c|c|c|c|c|c|}
\hline \multirow{2}{*}{ Country } & \multirow{2}{*}{ Name } & Cost & \multirow{2}{*}{$\underset{\text { Grant }}{\text { Annual }}$} & \multirow{2}{*}{$\begin{array}{l}\text { Receipts } \\
\text { from } \\
\text { annual } \\
\text { work }\end{array}$} & \multirow{2}{*}{$\begin{array}{c}\text { No. of } \\
\text { tests made }\end{array}$} & \multirow{2}{*}{ Staff } \\
\hline & & Building Equipment & & & & \\
\hline Germany $\ldots \quad \ldots$ & $\begin{array}{lll}\text { Reichsanstalt } & \ldots & \ldots \\
\text { Aichungs-kommission } & \ldots \\
\text { Versuchsanstalt } \quad \ldots & \ldots\end{array}$ & $\begin{array}{r}£ 200,000 \\
48,000 \\
137,000\end{array}$ & $\begin{array}{r}£ 16,000 \\
8,500 \\
15,000\end{array}$ & $\frac{£ 3,000^{2}}{-}$ & $\frac{22,469}{5, \infty 00}$ & $\frac{112}{140}$ \\
\hline $\begin{array}{lll}\text { France } & \ldots & \ldots\end{array}$ & Laboratoire de l'état & $\begin{array}{l}\qquad 3^{85}, 000 \\
£ 27, \infty 00 \quad £ 20,000 \\
\text { and some } \\
\text { buildings. }\end{array}$ & $\begin{array}{r}£ 39,500 \\
5,500\end{array}$ & $£ \mathrm{II}, 000$ & 27,469 & $\begin{array}{r}252 \\
12\end{array}$ \\
\hline $\begin{array}{l}\text { U.S.A. } \ldots . . . \\
\text { Great Britain.. }\end{array}$ & $\begin{array}{l}\text { Bureau of Standards } \\
\text { National Physical Laboratory }\end{array}$ & $\begin{array}{lc}£ 70,000 & 45,000 \\
£ 19,000 & \\
\text { including } & 1 \\
\text { some } & \\
\text { buildings. } & \end{array}$ & $\begin{array}{r}19,000 \\
4,000\end{array}$ & $\begin{aligned} 114^{* 3} \\
4,042^{4}\end{aligned}$ & $\begin{array}{r}1,666^{3} \\
30,807^{4}\end{array}$ & $\begin{array}{l}22 \\
50\end{array}$ \\
\hline
\end{tabular}

1 The annual grant was made before the work was started, and any balance left after paying salaries I believe was available for apparatus.

I might refer to researches in solar physics also, which are carried out in the iron shanties at South Kensington, under the control of the Board of Education. The sum of 70ol. is allotted as a grant in aid for the work that is carried out there, and some of the staff are borne on the estimates but if, as is to be believed, some of the tremendous problems of the causes of famine and plenty are dependent on the solar phenomena, then this work should be enlarged and encouraged. The expenditure of ten times the sum in one year may enable millions of pounds and lives to be saved which may be lost from the scant supply of needful means. It is true that the Solar Physics Observatory is under the Board of Education, but if its history were written, I doubt not that it would be found that from its very first inception (due to the repeated recommendation of a host of scientific men who foresaw something of what might be expected from it) the State wanted none of it. It may be said that if the Meteorological Office and the National Physical Laboratory were attached to a Government department, they might be starved in the same way. I do not believe it possible that such would be the case, for these two are of ostensible use to the ordinary public, and appeal to that most sagacious and popular person the man in the street, in a way that solar physics does not. The last deals with problems which are for future use, but it is intimately, most intimately, connected with meteorology. If the Meteorological Office becomes attached, as it eventually must be, to a Government department, the Solar Physics Observatory and staff should be attached to the same department.

If the Government will recognise the two institutions as doing essentially public service, and ask for the necessary funds, I believe Parliament would vote the supplies in the same ungrudging manner that Congress has done, as they would look upon them as a paying investment. Parliament realises most frequently before Government does the importance of any public work. The most happy solution of the problem would be (I) to have some department of State to which these and other kindred scientific institutions should be attached; (2) to have a scientific advisory board; (3) to distinguish clearly between grants for research, equipment, and material, and those for staff.

NO. 1830 , VOL. 7 I] which derives its name from that of one of its spurs which projects boldly towards the Atlantic, represents the wreck of the Upper Limestone of this district. The fertile undulating low grounds all around are occupied by a lower and more argillaceous series, through which one of the old Caledonian folds of Ireland projects as a knobby ridge, its rugged outlines forming a charming contrast with the green and grey tabular forms of the limestone. The Upper Limestone, 700 feet or 800 feet thick, massive and strongly jointed vertically, rests on the lower series as a cliff-bound plateau, intersected by several grand glens, which are cut through the limestone deep into the less resisting rocks underneath. The mural precipices are the result of the characteristic weathering of the massive limestones. Below them, where not obscured by talus, the Middle Limestones and shales fall away in steep concave slopes into the plain. The exquisite valleys of Glencar and Glenade cut right through the plateau, the first in an east and west direction, the other north and south. Each is from one to two miles wide from cliff-top to cliff-top, and about a thousand feet deep (Fig. I). The fioors of these valleys are undulating, and the scenery is much enhanced by the fact that each embosoms a lake at the point where the cliff scenery reaches its best.

On some parts of the plateau-edge denudation has been more severe, as in the beautiful wedge of Ben Whiskin (1666 feet), the western side of which displays a characteristic precipitous front, while the eastern side has been worn down to a uniform steep slope which drops into Gleniff.

The uniformity of the post-Carboniferous uplift is shown by the almost absolute horizontality of the beds of limestone throughout the region. The surface of the plateau, while retaining in a general way this horizontality, is seen on a nearer approach to be undulating, a feature chiefly due to the fact that patches of the Yoredale sandstone still remain here and there isolated on the surface of the limestone. The whole plateau, limestone as well as sandstone, has in general a thick covering of peat.

To the botanist the Ben Bulben range is well known as the only British habitat of Arenaria ciliata, a species with a high northern and alpine distribution, which is locally 
abundant on these hills. This plant strikes the key-note of the flora of the district, which is essentially northern and alpine in its characters. Adjoining on the south, in Mayo, the Lusitanian heaths, Erica mediterranea and Dabeocia polifolia, and other plants fully represent the remarkable southern flora which characterises the western sea-board of Ireland, and a few miles on the northern side the same features are repeated in Donegal in the occurrence of Saxifraga umbrosa, Euphorbia hiberna, and Trichomanes radicans. But in the Sligo flora the southern element is absent, saving the occurrence of Adiantum Capillus-Veneris, which may be found growing at sea-level in company with Draba incana and Saxifraga aizoides.

As it is with the plants, so with the animals. The characteristic southern forms of western Ireland are scarcely represented, while northern animais are conspicuous. The Field Club entomologists found Pclophila borealis literally to swarm on the shores of Lough Gill, which is only a few feet above sea-level : Xenylla brcvicauda, an Apteron new fined to the erosion taking place on the Yorkshire coast between Bridlington and Spurn, and the works that have been carried out in constructing promenades, sea walls, and groynes at Bridlington.

There is no novelty in the descriptive parts of these papers. It is a well known and recognised fact that on certain parts of the coast of this country considerable loss of land is taking place by the erosion of the sea. The subject occupied the attention of the geological section of the British Association in 1885 , when a committee was appointed to investigate the subject of coast erosion, and reports of experts having local knowledge were obtained from all parts of the coast and printed in the reports issued from time to time, the last, which was confined to recent evidence obtained from the coast guards, being published in the report of the meeting held at Southport in 1903 . We have ourselves dealt with the subject in articles in NATURE in our number for June, 1899 , and on sea coast and destruction in August 23 , 1900. The destruction of the Holderness

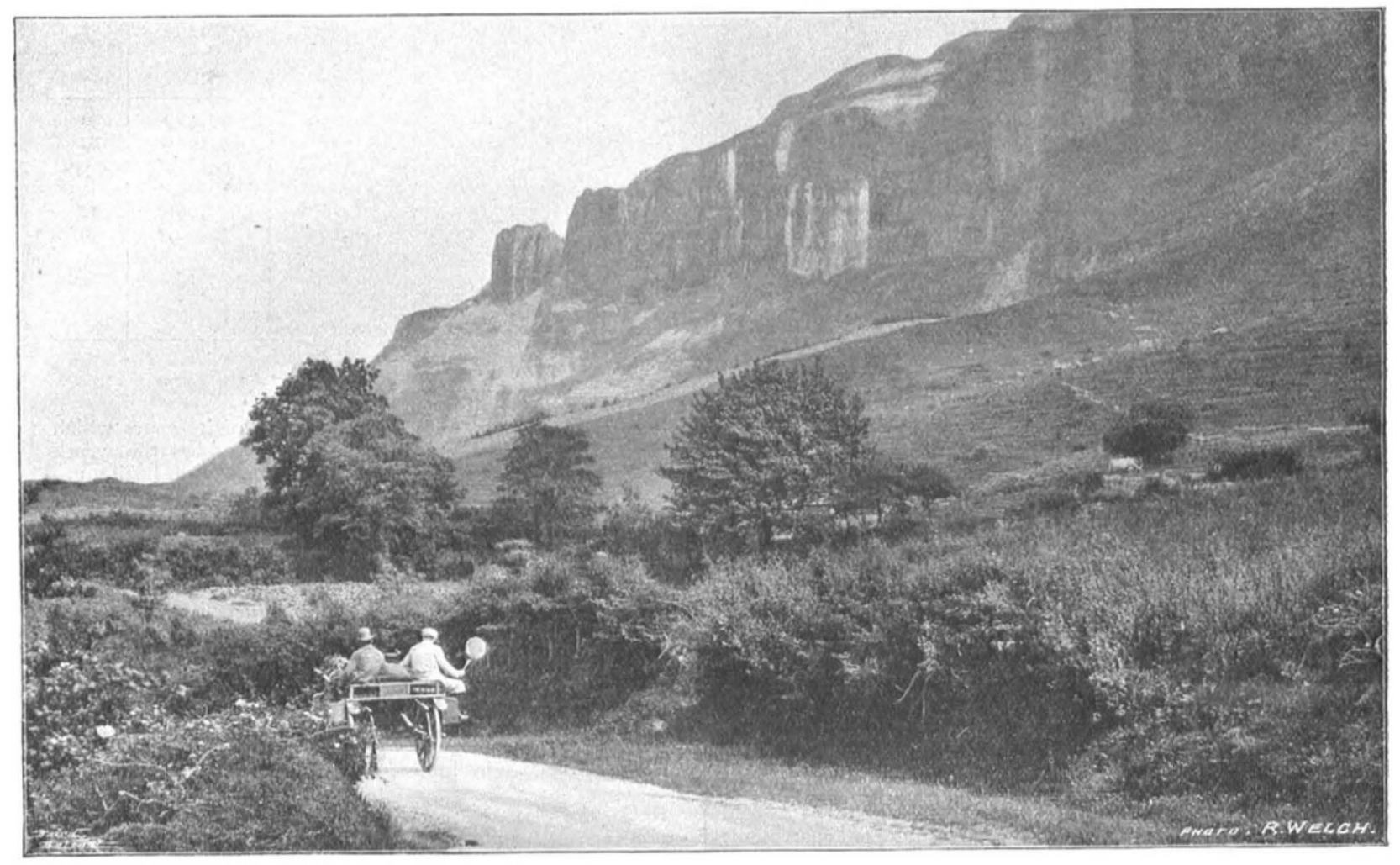

FIG. 1.-Entrance of Glencar. Showing the southern cliff.wall of Carboniferous Limestone, which rises a thousand feet above the valley.

to the British Isles, which accompanied it here, is likewise northern; and other instances might be quoted. Among other results of the Field Club visit (which are fully described in the September number of the Irish Naturalist) may be mentioned the discovery of three water-mites, one of which, Eylais bicornuta, is new to science, and the two others new to Britain.

\section{COAST EROSION AND PROTECTION.}

TWO papers on this subject were recently read at the 1 Institution of Civil Engineers, one by $\mathrm{Mr}$. A. E. Carey on coast erosion, and the other by Mr. E. R. Matthews, the borough engineer of Bridlington, on the erosion of the Holderness coast of Yorkshire.

The first paper deals generally with the whole coast of England, and briefly enumerates the salient geological features of the coast line and points out their connection with the relative rates of erosion. The second paper is conNo. I 830 , VOL. 7 I] coast and the protective works put up to stop the erosion at Hornsea, Withernsea, and Spurn were dealt with in a paper by Mr. Pickwell on the encroachments of the sea from Spurn Point to Flamborough Head printed in the Minutes of Proceedings of the Institution of Civil Engineers, vol. li., 1878 .

The whole subject, both as descriptive of the coast of England, the losses that have taken place, and the works that have been carried out to prevent erosion, is also very fully dealt with in the work on "The Sea Coast" published by Messrs. Longmans in 1902.

Mr. Matthews in his paper makes a statement that has frequently been made before, but for which there does not appear to be any warrant, to the effect that the material eroded from the Holderness coast is carried into the estuary of the Humber. This subject was very fully dealt with in a paper read at the British Association at Glasgow in Igor on the source of warp in the Humber, in which it was conclusively shown that it is physically impossible for this material to be carried into the Humber, and that, as a 